\section{Methyl lodide plus Chloropicrin Rates and Formulations for Nutsedge Management in Tomato}

\author{
James P. Gilreath ${ }^{1}$ and Bielinski M. Santos ${ }^{2,3}$
}

ADDITIONAL INDEX wORDs. Lycopersicum esculentum, Solanum lycopersicum, Cyperus spp., weed control, soil fumigation, methyl bromide, iodomethane

Summary. Two independent field studies were conducted to determine the efficacy of methyl iodide (MI) formulations and rates on mixed nutsedge [purple nutsedge (Cyperus rotundus) and yellow nutsedge (Cyperus esculentus)] stands and their effects on tomato (Solanum lycopersicum) yields. In both studies, treatments were rates of two formulations of $M I+$ chloropicrin (Pic) at the 98:2 (v/v) and 50:50 (v/ v) proportions. In the $\mathrm{MI}+\operatorname{Pic} 98: 2$ study, the fumigant rates were $0,100,125$, 150,175 , and $200 \mathrm{lb} /$ acre in Spring 2004 and $0,125,150,175$, and $200 \mathrm{lb} /$ acre in Fall 2004. In the MI + Pic 50:50 study, the rates were 0, 200, 250, 300, 350, and $400 \mathrm{lb} /$ acre during both seasons. Additionally, a grower standard was included in each study, which consisted of plots fumigated with methyl bromide $(\mathrm{MBr})+\mathrm{Pic}$ 67:33 (v/v) at a rate of $350 \mathrm{lb} /$ acre. Higher rates of $\mathrm{MI}+$ Pic 98:2 and 50:50 significantly reduced mixed nutsedge densities and increased relative marketable fruit weight of tomato. Plots fumigated with $\mathrm{MBr}+\mathrm{Pic}$ were weed-free at the sampling times during both studies. Data from both studies indicated that $\mathrm{MI}+\mathrm{Pic}$ 98:2 and 50:50 rates of 125 and $200 \mathrm{lb} /$ acre, respectively, consistently provided the highest marketable fruit weights and mixed nutsedge control, which were similar to those obtained in plots treated with $\mathrm{MBr}+$ Pic.

S oil fumigation is a common pest control activity to prepare a field for vegetable crop production under plasticulture in many countries throughout the world, including the United States. Until recently, fumigation with $\mathrm{MBr}$ in combination with Pic was used to effectively control the majority of soilborne pests. However, $\mathrm{MBr}$ has been phased out because it is an ozone-depleting molecule (Watson et al., 1992). Among the many weeds controlled by $\mathrm{MBr}+\mathrm{Pic}$, nutsedges (Cyperus spp.) are the most troublesome to control. These weeds thrive in environments with high sunlight and high temperatures in tropical and subtropical areas of the world. Nutsedges are among the most difficult-to-control weeds in vegetable crops, competing for light, water, nutrients, and space and having allelopathic effects on other species (Holm et al., 1977). These weeds exhibit rapid growth and development of underground asexual reproductive structures, such as tubers and rhizomes, which allow them to

Gulf Coast Research and Education Center, IFAS, University of Florida, 14625 CR 672, Wimauma, FL 33598

${ }^{1}$ Retired Professor

${ }^{2}$ Assistant Professor

${ }^{3}$ Corresponding author. E-mail: bmsantos@ufl.edu. survive in stressful field conditions (Williams, 1982). When mixed stands of nutsedges are not controlled in a timely manner, they penetrate through plastic mulch and compete with vegetable crops. Several studies have demonstrated the extent of yield losses caused by nutsedges. In bell pepper (Capsicum annuum), radish (Raphanus sativus), and cilantro (Coriandrum sativum), marketable yield losses reached $73 \%, 100 \%$, and $61 \%$, respectively, due to intense nutsedge interference (Gilreath et al., 2005; Morales-Payan et al., 1999; Santos et al., 1998).

Tomato is the leading vegetable crop in Florida, where $\approx 33,600$ acres are planted annually mostly in the warm climates of the southern and production value of about $\$ 520$ million (U.S. Department of Agriculture, 2010). Because of the importance of the crop, controlling nutsedges west-central part of the state, with a effectively without $\mathrm{MBr}$ has become a challenge for the industry. Previous research indicated that season-long nutsedge interference at a density of 10.5 plants $/ \mathrm{ft}^{2}$ caused a $51 \%$ tomato yield loss in comparison with the weedfree control (Gilreath and Santos, 2004). Stall and Morales-Payan (2003) suggested that the critical period of purple nutsedge interference occurs between 2 and 7 weeks after transplanting (WAT) tomato, which coincides with the periods of rapid plant growth and flowering.

Among the multiple soil fumigants being tested for replacing $\mathrm{MBr}$, the combination of MI + Pic could be one of the most promising. However, previous studies have had mixed results on the efficacy of MI + Pic on nutsedge control. Uhlig et al. (2007) found inconsistent control of several broadleaf species with $\mathrm{MI}+\operatorname{Pic} 50: 50(\mathrm{v} / \mathrm{v})$ at $200 \mathrm{lb} /$ acre in seven ornamental species. However, the same study determined that MI + Pic 98:2(v/v) at 350 $\mathrm{lb} / \mathrm{acre}$ was as effective as $\mathrm{MBr}+\mathrm{Pic}$ 67:33 (v/v) on controlling the weeds. In garden rose (Rosa multiflora) nurseries, shank-injected MI + Pic 67:33 $(\mathrm{v} / \mathrm{v})$ at $300 \mathrm{lb} /$ acre performed comparable to $\mathrm{MBr}+\operatorname{Pic} 98: 2(\mathrm{v} / \mathrm{v})$ at $400 \mathrm{lb} /$ acre (Schneider et al., 2009). Schneider and Hanson (2009) suggested that application of MI + Pic at both 30:70 and 50:50 (v/v) proportions at rates between 358 and $427 \mathrm{lb} /$ acre provided weed control similar to $\mathrm{MBr}+\operatorname{Pic}$ 98:2 (v/v) at $512 \mathrm{lb} / \mathrm{acre}$. Fennimore et al. (2008) recommended the application of MI + Pic 50:50 $(\mathrm{v} / \mathrm{v})$ at $350 \mathrm{lb} /$ acre to control broadleaf weeds at levels comparable to $\mathrm{MBr}+\mathrm{Pic}$ 57:43 (v/v) at $395 \mathrm{lb} /$ acre in strawberry (Fragaria $\times$ ananassa) nurseries, while other studies found no detrimental effects of $\mathrm{MI}+$ Pic fumigation on strawberry yields in comparison with those obtained with $\mathrm{MBr}+\mathrm{Pic}$ (Kabir et al., 2005).

The cost of fumigants containing $\mathrm{MI}$ is an additional concern for vegetable growers who fumigate under

\begin{tabular}{llll}
\hline $\begin{array}{l}\text { Units } \\
\begin{array}{l}\text { To convert U.S. to SI, } \\
\text { multiply by }\end{array}\end{array}$ & U.S unit & SI unit & $\begin{array}{l}\text { To convert SI to U.S., } \\
\text { multiply by }\end{array}$ \\
\hline 0.4047 & $\mathrm{acre}(\mathrm{s})$ & $\mathrm{ha}$ & 2.4711 \\
0.3048 & $\mathrm{ft}$ & $\mathrm{m}$ & 3.2808 \\
0.0929 & $\mathrm{ft}^{2}$ & $\mathrm{~m}^{2}$ & 10.7639 \\
2.54 & inch $(\mathrm{es})$ & $\mathrm{cm}$ & 0.3937 \\
1.1209 & $\mathrm{lb} / \mathrm{acre}$ & $\mathrm{kg} \cdot \mathrm{ha}^{-1}$ & 0.8922 \\
0.0254 & mil & $\mathrm{mm}$ & 39.3701
\end{tabular}


plastic mulch. Therefore, the efficacious combinations of MI and Pic must be also cost-effective. Furthermore, the current cost of $\mathrm{MI}$ is about twice that of Pic, which mostly provides soilborne disease control. Thus, the greater the concentration of Pic, the lower is the cost per unit of formulated product. Sydorovych et al. (2008) determined that application of $\mathrm{MI}+$ Pic 50:50 (v/v) at $300 \mathrm{lb} /$ acre showed adequate performance, adding to tomato yield estimates relative to $\mathrm{MBr}+\mathrm{Pic} 67: 33(\mathrm{v} / \mathrm{v})$ at $400 \mathrm{lb} /$ acre, but the high cost of MI + Pic partially offset yield advantages, resulting in $\$ 425$ /acre less revenue than that obtained with $\mathrm{MBr}+\mathrm{Pic}$. The effective rate of application and the most effective formulation (proportion) of both a.i. against nutsedges need to be identified. To provide a product that is both efficacious and affordable, studies were conducted to determine 1 ) the efficacy of MI formulations and rates on mixed-nutsedge stands and 2) their effects on tomato yields.

\section{Materials and methods}

Two concurrent, separate studies were conducted over two seasons each (Spring and Fall 2004) in a tomato grower field near Ruskin, FL. The soil at the experimental site is a deep, sandy Spodosol with organic matter content of $1.5 \%$ and $\mathrm{pH}$ of 7.4 . The site has a history of heavy infestation of a mixed stand of both nutsedge species $(\approx 80 \%$ purple nutsedge). Before the studies, the soil was disked twice to ensure proper structure for fumigant application. Afterward, planting beds were formed at $5 \mathrm{ft}$ on centers. Bed dimensions were 24 inches wide at the top, 28 inches wide at the base, and 8 inches tall. Within $1 \mathrm{~min}$ after fumigant application, beds were covered with l-mil-thick black on white high-density polyethylene mulch film (Intergro, Clearwater, FL) in Spring and Fall 2004.

Soil fumigants were applied to planting beds before mulching with a fumigant injector equipped with three gas knives spaced 10 inches apart and delivering the products 8 inches deep. In both studies, treatments consisted of rates of two formulations of MI + Pic (98:2 and 50:50). In the MI + Pic 98:2 study, the fumigant rates were $0,100,125$, 150,175 , and $200 \mathrm{lb} /$ acre in the Spring 2004 trial and $0,125,150$, 175 , and $200 \mathrm{lb} /$ acre in the Fall 2004 study. In the MI + Pic 50:50 study, the rates during both seasons were 0 , $200,250,300,350$, and $400 \mathrm{lb} /$ acre. Additionally, a grower standard was included in each study, which consisted of plots fumigated with $\mathrm{MBr}+$ Pic 67:33 (v/v) at a rate of $350 \mathrm{lb} /$ acre. Six-week-old 'Florida-47' tomato seedlings were transplanted 3 weeks after fumigation using an inrow distance of $2 \mathrm{ft}$ in the center of the plots. The experimental unit consisted of one 50 - $\mathrm{ft}$-long section of bed (25 plants/plot). A randomized complete block design with six replications was used on each study.

Subsurface irrigation was provided on a regular basis as required to maintain the water table between 18 and 24 inches below bed tops. Water table depth was monitored with observation wells located within each experiment. Tomato plants were staked and tied between three and four times during the season, depending on canopy growth. Pest management and fertilization practices followed current recommendations for tomato production in Florida (Olson et al., 2006). In each study, nutsedge densities were determined at 5 and 9 WAT in Spring 2004 and at 3 and 9 WAT in Fall 2004. The cumulative shoot emergence densities through the polyethylene mulch were counted over the whole experimental area of each treatment. Tomato fruit were harvested twice at 12 and 14 WAT from all plants in each plot, and fruit were separated into marketable and non-marketable according to current market standards (Sargent et al., 2005). Relative marketable fruit weight was calculated as the proportion of marketable fruit obtained in the $\mathrm{MBr}+\mathrm{Pic}$ plots, which represented $100 \%$ relative yield, to allow direct comparisons between the growers' standard practice and the new fumigant formulations and rates. For each study, nutsedge density and relative yield data were tested for normality and analyzed individually using regression analysis $(P<0.05)$, and standard error bars were used to separate specific treatment means [Statistix (version 7; Analytical Software, Tallahassee, FL) and SAS (version 9.1; SAS Institute, Cary, NC)].

\section{Results and discussion}

EFFeCts OF MI + PiC 98:2 RATES ON NUTSEDGE DENSITIES AND TOMATO YIELDS. There were significant season- by-treatment effects on nutsedge densities and tomato marketable yields. Therefore, data from each season were analyzed separately. Rates of MI + Pic 98:2 significantly reduced nutsedge densities and relative marketable fruit weight of tomato. Plots fumigated with $\mathrm{MBr}+\mathrm{Pic}$ were weed-free at the sampling times during both planting seasons. In spring 2004, nutsedge densities at 5 and 9 WAT declined exponentially in response to increased MI + Pic 98:2 (Fig. 1). Non-fumigated plots had the highest nutsedge densities during both sampling dates with 54,500 and 97,400 plants/acre, respectively. Based on the regression model for nutsedge densities at 5 WAT, a MI + Pic 98:2 rate of 175 $\mathrm{lb} /$ acre would reduce nutsedge populations to 8300 plants/acre, which is lower than a density of 9200 plants/ acre needed for causing a 10\% tomato yield loss (Stall and Morales-Payan, 2003). Furthermore, lowering MI + Pic 98:2 rates to $125 \mathrm{lb} /$ acre resulted in similar nutsedge control with higher fumigant rates. At 9 WAT, the application of $175 \mathrm{lb} /$ acre of MI + Pic 98:2 or more decreased nutsedge densities below 30,000 plants/ acre.

During the same season, relative tomato marketable fruit weight increased quadratically with $\mathrm{MI}+\mathrm{Pic}$ 98:2 rates (Fig. 1). Tomato marketable fruit weight in the non-treated control was $47 \%$ lower compared with the weed-free $\mathrm{MBr}+$ Pic-treated plots. When the soil was fumigated with MI + Pic 98:2, there was a sharp increase on relative tomato marketable fruit weight, regardless of the applied rates. On the basis of the observed values, there were no relative fruit weight differences among the plots treated with $\mathrm{MBr}+\mathrm{Pic}$ and those treated with $\mathrm{MI}+\mathrm{Pic}$ 98:2 rates between 125 and $200 \mathrm{lb} /$ acre. However, a MI + Pic rate of $100 \mathrm{lb} /$ acre failed to reach the relative fruit weight levels of the other fumigated treatments $(\approx 92 \%$ of the $\mathrm{MBr}+\mathrm{Pic}$ plots).

In Fall 2004, nutsedge densities at 3 and 9 WAT declined linearly as MI + Pic 98:2 rates increased (Fig. 2). At 3 WAT, there were no significant differences among the observed nutsedge densities in plots treated with either 175 or $200 \mathrm{lb} /$ acre of MI + Pic and those fumigated with $\mathrm{MBr}+\mathrm{Pic}$ (weed-free control). Additionally, 


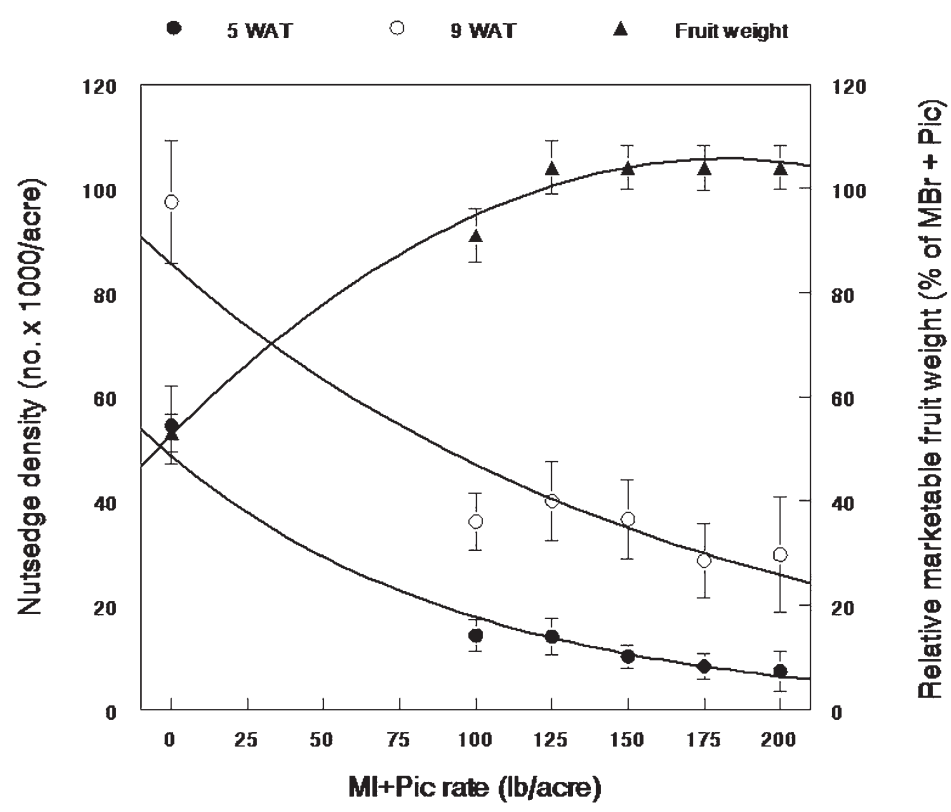

Fig. 1. Effects of methyl iodide plus chloropicrin (MI + Pic) 98:2 (v/v) rates on nutsedge densities at $\mathbf{5}$ and 9 weeks after transplanting (WAT) and on relative tomato marketable fruit weight in plots treated with methyl bromide plus chloropicrin $(\mathrm{MBr}+\mathrm{Pic})$ 67:33 (v/v) at a rate of $350 \mathrm{lb} / \mathrm{acre}$ in Spring 2004 at Ruskin, FL. Regression equations were $y=48.68 \mathrm{e}^{-0.0101 x}$ (5 WAT); $y=85.53 \mathrm{e}^{-0.0060 x}(9 \mathrm{WAT}) ;$ and $y=52.6527+0.5823 x-0.0016 x^{2}$ (fruit weight); $1 \mathrm{lb} /$ acre $=0.8922 \mathrm{~kg} \cdot \mathrm{ha}^{-1}, 1000 /$ acre $=2471.0538 / \mathrm{ha}$.

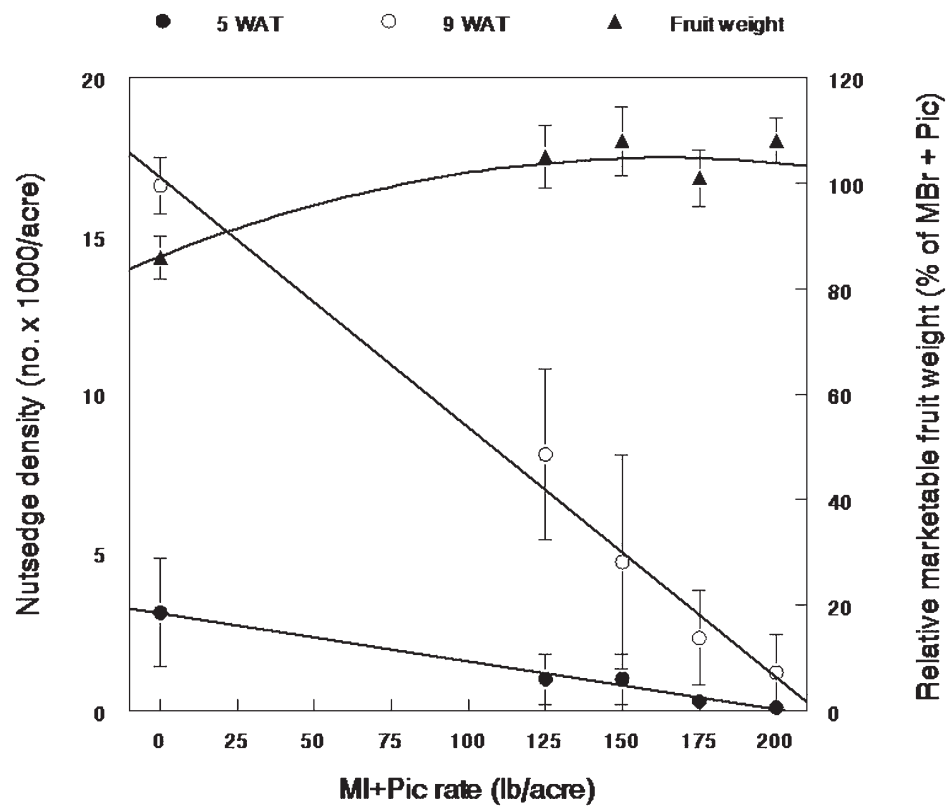

Fig. 2. Effects of methyl iodide plus chloropicrin $(M I+P i c)$ 98:2 (v/v) rates on nutsedge densities at 3 and 9 weeks after transplanting (WAT) and on relative tomato marketable fruit weight in plots treated with methyl bromide plus chloropicrin $(\mathrm{MBr}+\mathrm{Pic})$ 67:33 (v/v) at a rate of $350 \mathrm{lb} /$ acre in Fall 2004 at Ruskin, FL. Regression equations were $y=3.0701-0.0152 \times(3 \mathrm{WAT})$; $y=16.8567-0.0791 \times(9$ WAT $) ;$ and $y=86.1377+0.2290 x-0.0007 x^{2}$ (fruit weight); $1 \mathrm{lb} /$ acre $=0.8922 \mathrm{~kg} \cdot \mathrm{ha}^{-1}, 1000 /$ acre $=2471.0538 / \mathrm{ha}$.

plots fumigated with $125 \mathrm{lb} /$ acre of MI + Pic 98:2 or more resulted in nutsedge densities of $\approx 1100$ plants/ acre. At 9 WAT, all plots fumigated with MI + Pic 98:2 had nutsedge densities below 9200 plants/acre, which is the critical density to reduce tomato yields by $10 \%$. The only treatment with a nutsedge densities equivalent to that of the weed-free control $(\mathrm{MBr}+\mathrm{Pic}$ plots $)$ was $\mathrm{MI}+$ Pic 98:2 at 175 and $200 \mathrm{lb} /$ acre.

Relative tomato marketable fruit weight steadily increased with MI + Pic 98:2 rates (Fig. 2). A quadratic relationship characterized the response of the crop to fumigation rates. Seasonlong nutsedge interference reduced relative tomato yield by $14 \%$ in the non-fumigated control plots. There were no significant differences in relative fruit weights between the plots treated with MI + Pic 98:2 and those injected with $\mathrm{MBr}+$ Pic. During both the growing seasons, plots treated with MI + Pic 98:2 rates of $125 \mathrm{lb} /$ acre or more resulted in similar relative tomato yields as those for $\mathrm{MBr}+\mathrm{Pic}$. These results indicated that MI + Pic 98:2 rates of $125 \mathrm{lb} /$ acre are sufficient to control nutsedge densities, while maintaining yields at the same level as those reached in $\mathrm{MBr}+\mathrm{Pic}$ plots.

EfFects of MI + Pic 50:50 RATES ON NUTSEDGE DENSITIES AND TOMATO YIELDS. There were significant season-by-treatment interactions, thus each season was analyzed separately. In spring 2004, two exponential equations characterized nutsedge density responses to $\mathrm{MI}+$ Pic 50:50 rates (Fig. 3). As Mi + Pic 50:50 increased, nutsedge densities decayed exponentially at 5 and 9 WAT. Non-fumigated plots had average nutsedge densities of 54,500 and 97,400 plants/acre, which suggested substantial weed pressure for these studies. During the first sampling date, there were no significant differences on nutsedge densities between $\mathrm{Mi}+$ Pic 50:50 rates of 200 $\mathrm{lb} / \mathrm{acre}$ or more and the weed-free plots treated with $\mathrm{MBr}+\mathrm{Pic}$. However, at 9 WAT, observed nutsedge densities ranged between 6900 and 17,100 plants/acre. Nutsedge interference with the crop caused a marketable fruit weight reduction of $49 \%$ in the non-fumigated control plots (Fig. 3 ). There were no differences among the relative marketable fruit weights obtained with $\mathrm{Mi}+\mathrm{Pic}$ 50:50 rates between 200 and $400 \mathrm{lb} /$ acre, all of which were statistically equal to $\mathrm{MBr}+$ Pic-treated plots.

Nutsedge densities at 3 and 9 WAT declined rapidly as $\mathrm{MI}+\mathrm{Pic}$ 50:50 rates increased from 0 to 200 $\mathrm{lb}$ /acre during Fall 2004, remaining below 1100 plants/acre with higher fumigant rates (Fig. 4). There were no 


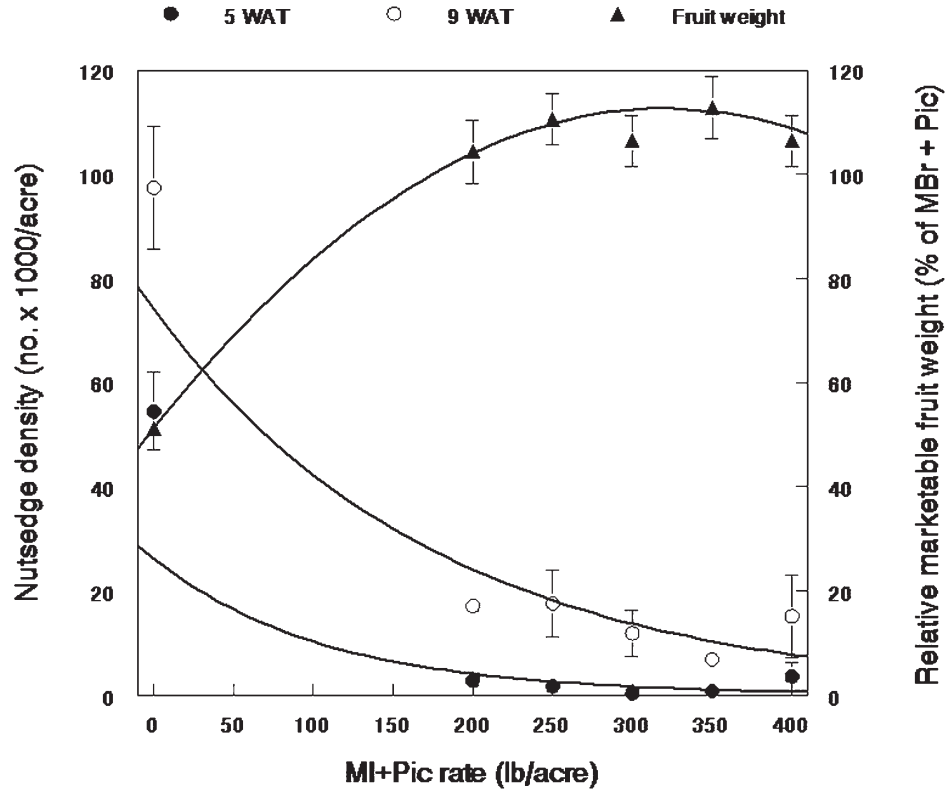

Fig. 3. Effects of methyl iodide plus chloropicrin $(\mathrm{MI}+\mathrm{Pic})$ 50:50 (v/v) rates on nutsedge densities at 5 and 9 weeks after transplanting (WAT) and on relative tomato marketable fruit weight in plots treated with methyl bromide plus chloropicrin $(\mathrm{MBr}+\mathrm{Pic})$ 67:33 (v/v) at a rate of $350 \mathrm{lb} /$ acre in Spring 2004 at Ruskin, FL. Regression equations were $y=26.25 \mathrm{e}^{-0.0093 x}$ (5 WAT); $y=74.16 \mathrm{e}^{-0.0056 x}\left(9\right.$ WAT); and $y=51.2971+0.3837 x-0.0006 x^{2}$ (fruit weight); $1 \mathrm{lb} /$ acre $=0.8922 \mathrm{~kg} \cdot \mathrm{ha}^{-1}, 1000 /$ acre $=2471.0538 / \mathrm{ha}$.

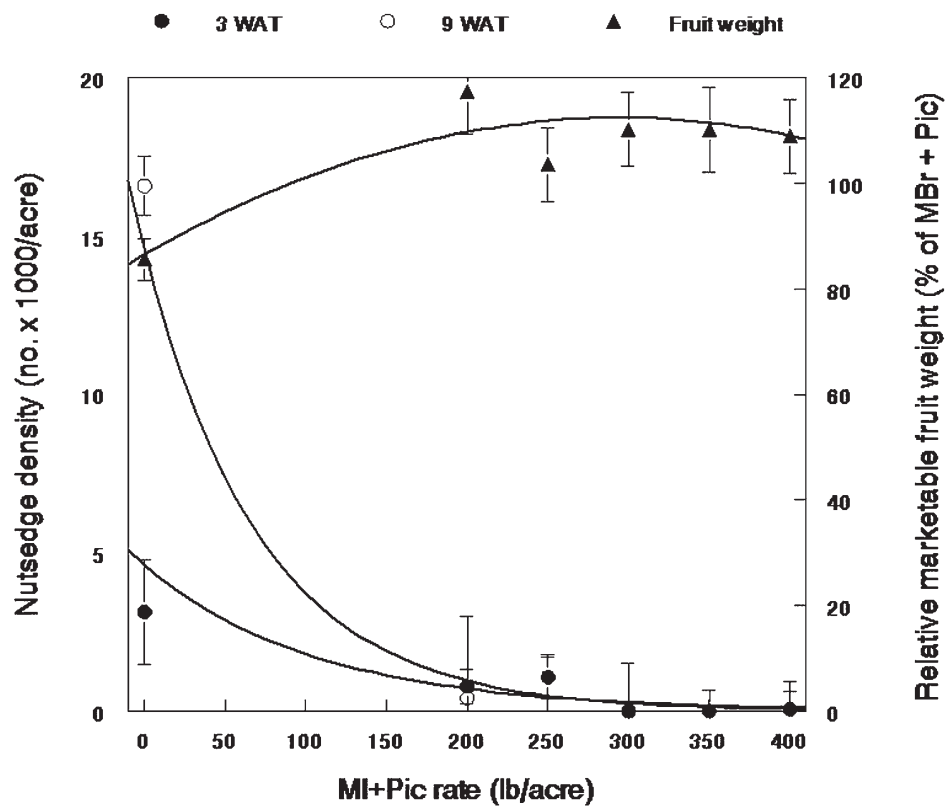

Fig. 4. Effects of methyl iodide plus chloropicrin $(M I+P i c) 50: 50(v / v)$ rates on nutsedge densities at 3 and 9 weeks after transplanting (WAT) and on relative tomato marketable fruit weight in plots treated with methyl bromide plus chloropicrin $(\mathrm{MBr}+\mathrm{Pic}) 67: 33(\mathrm{v} / \mathrm{v})$ at a rate of $350 \mathrm{lb} / \mathrm{acre}$ in Fall 2004 at Ruskin, FL. Regression equations were $y=4.62 \mathrm{e}^{-0.0094 x}(3 \mathrm{WAT}) ; y=14.60 \mathrm{e}^{-0.0136 x}$ (9 WAT); and $y=86.4672+0.1766 x-0.0003 x^{2}$ (fruit weight); $1 \mathrm{lb} /$ acre $=$ $0.8922 \mathrm{~kg} \cdot \mathrm{ha}^{-1}, 1000 /$ acre $=2471.0538 / \mathrm{ha}$.

differences in nutsedge densities when MI + Pic 50:50 rates were $200 \mathrm{lb} /$ acre or more at both sampling dates, and these were comparable to the weed- free $\mathrm{MBr}+$ Pic plots. The non-treated control plots had nutsedge densities of 3100 and 16,600 plants/acre at 3 and 9 WAT, respectively. Relative marketable fruit weight of tomato increased quadratically with $\mathrm{MI}+$ Pic 50:50 rates, with the non-treated control producing $14 \%$ less than the fumigated treatments (Fig. 4). All the MI+ Pic 50:50 rates (200 lb/acre or more) produced the same yields as that obtained in the $\mathrm{MBr}+$ Pic-treated plots.

In summary, the data from both studies indicated that MI + Pic 98:2 and 50:50 rates of 125 and $200 \mathrm{lb} /$ acre, respectively, consistently provided the highest marketable fruit weights, which were similar to those obtained in plots treated with $\mathrm{MBr}+$ Pic. These rates are equivalent to 120 and $100 \mathrm{lb} /$ acre of MI, respectively, under highly retentive polyethylene mulch. From the economical standpoint, $\mathrm{MI}$ is a more expensive fumigant than $\mathrm{MBr}$; thus, growers should base their decisions on the efficacy and the costs of the product. Replacing $\mathrm{MBr}+\mathrm{Pic}$ with $\mathrm{MI}+$ Pic 50:50 may result in lower fumigation costs because of the lower content of $\mathrm{MI}$ in that formulation in comparison with the corresponding 98:2. Furthermore, the increased amount of Pic in the 50:50 formulation, which provide $100 \mathrm{lb} /$ acre of Pic when applying a rate of $200 \mathrm{lb} /$ acre of MI + Pic 50:50, will provide additional soilborne disease control that is not expected in the MI + Pic 98:2 formulation. A previous study had determined that MI + Pic 50:50 at $300 \mathrm{lb} /$ acre was too costly to replace $\mathrm{MBr}+\operatorname{Pic} 67: 33$ at $400 \mathrm{lb} /$ acre in tomato, in spite of adequate yield performance (Sydorovych et al., 2008). In this case, excellent nutsedge control and tomato yields similar to those obtained with $\mathrm{MBr}+\mathrm{Pic}$ were achieved with rates below $300 \mathrm{lb} /$ acre of $\mathrm{MI}+$ Pic 50:50.

\section{Literature cited}

Fennimore, S.A., M.J. Haar, R.E. Goodhue, and C.Q. Winterbottom. 2008. Weed control in strawberry runner plant nurseries with methyl bromide alternative fumigants. HortScience 43:1495-1500.

Gilreath, J.P. and B.M. Santos. 2004. Manejo de Cyperus rotundus con alternativas al bromuro de metilo en tomate de mesa. Manejo Integrado de Plagas y Agroecología 71:54-58.

Gilreath, J.P., T.N. Motis, and B.M. Santos. 2005. Cyperus spp. control with reduced methyl bromide plus chloropicrin rates under virtually impermeable films in pepper. Crop Protection 24:285-287. 
Holm, L.G., D.L. Plucknett, J.V. Pancho, and J.P. Herberger. 1977. The world's worst weeds: Distribution and biology. Univ. Press of Hawaii, Honolulu, HI.

Kabir, Z., S.A. Fennimore, J.M. Duniway, F.N. Martin, G.T. Browne, C.Q. Winterbottom, H.A. Ajwa, B.B. Westerdahl, R.E. Goodhue, and M.J. Haar. 2005. Alternatives to methyl bromide for strawberry runner plant production. HortScience 40: 1709-1715.

Morales-Payan, J.P., B.M. Santos, W.M. Stall, and T.A. Bewick. 1999. Influence of nitrogen fertilization on the competitive interactions of cilantro (Coriandrum sativum) and purple nutsedge (Cyperus rotundus). J. Herbs Spices Med. Plants 6:59-66.

Olson, S.M., W.M. Stall, M.T. Momol, S.E. Webb, T.G. Taylor, S.A. Smith, E.H. Simonne, and E. McAvoy. 2006. Tomato production in Florida, p. 407-426. In: S.M. Olson and E.H. Simonne (eds.). Vegetable production handbook for Florida, 2006-2007. Inst. Food Agr. Sci. Publ., Univ. of Florida, Gainesville, FL.
Santos, B.M., J.P. Morales-Payan, W.M. Stall, and T.A. Bewick. 1998. Influence of purple nutsedge (Cyperus rotundus) density and nitrogen rate on radish (Raphanus satious) yield. Weed Sci. 46:661-664.

Sargent, S.A., J.K. Brecht, and T. Olczyk. 2005. Handling Florida vegetable seriesRound and Roma tomato types. 21 Nov. 2009. <http://edis.ifas.ufl.edu/pdffiles/ $\mathrm{VH} / \mathrm{VH} 07900 . p d f>$

Schneider, S.M. and B.D. Hanson. 2009. Effects of fumigant alternatives to methyl bromide on pest control in open field nursery production of perennial fruit and nut plants. HortTechnology 19:526-532.

Schneider, S.M., B.D. Hanson, J.S. Gerik, A. Shrestha, T.J. Trout, and S. Gao. 2009.

Comparison of shank- and drip-applied methyl bromide alternatives in perennial crop field nurseries. HortTechnology 19: 331-339.

Stall, W.M. and J.P. Morales-Payan. 2003. The critical period of nutsedge interference in tomato. 17 July 2006. <http://swfrec.ifas.ufl.edu/LIV/groups/ IPM/weed_con/nutsedge.htm>.
Sydorovych, O., C.D. Safley, R.M. Welker, L.M. Ferguson, D.W. Monks, K. Jennings, J. Driver, and F.J. Louws. 2008. Economic evaluation of methyl bromide alternatives for the production of tomatoes in North Carolina. HortTechnology 18:705-713.

U.S. Department of Agriculture. 2010. Vegetables: 2009 summary. 21 Nov. 2009. <http://usda.mannlib.cornell.edu/ usda/current/VegeSumm/VegeSumm01-27-2010.pdfs.

Uhlig, R.E., G. Bird, R.J. Richardson, and B.H. Zandstra. 2007. Soil fumigants to replace methyl bromide for weed control in ornamentals. HortTechnology 17:111114.

Watson, R.T., D.T. Albritton, S.O. Anderson, and S. Lee-Bapty. 1992. Methyl bromide: Its atmospheric science, technology and economics. Montreal Protocol Assessment Suppl., United Nations Environ. Programme, Nairobi, Kenya.

Williams, R.D. 1982. Growth and reproduction of Cyperus esculentus L. and Cyperus rotundus L. Weed Res. 22:149-154. 